\title{
Wpływ pokrycia powierzchni cementów szkło-jonomerowych powłoką nanokompozytową na ich wybrane właściwości
}

\author{
The influence of surface nanocomposite coating on selected properties \\ of glass-ionomer cements
}

\author{
${ }^{1}$ Uczelniane Laboratorium Badań Materiałowych, Uniwersytet Medyczny w Łodzi \\ 2 Zakład Stomatologii Zachowawczej, Uniwersytet Medyczny w Łodzi \\ ${ }^{3}$ Uczelniane Laboratorium Ruchu i Wydolności Fizycznej Człowieka „DynamoLab” \\ Uniwersytet Medyczny w Łodzi \\ ${ }^{4}$ Zakład Stomatologii Ogólnej, Uniwersytet Medyczny w Łodzi
}

DOI: http://dx.doi.org/10.20883/df.2017.17

\begin{abstract}
Streszczenie
Wstęp. Cementy szkło-jonomerowe (GIC) są szeroko stosowane w stomatologii odtwórczej. Jest to związane z zaletami, jakimi odznaczają się te materiały. Ze względu na wymagania stawiane współczesnym materiałom stomatologicznym oraz możliwości, jakie niesie ze sobą zastosowanie GIC, prowadzone są badania nad modyfikacjami ich warstwy wierzchniej w celu poprawienia ich właściwości mechanicznych oraz estetycznych.

Cel. Celem pracy była ocena wpływu pokrycia powierzchni cementów szkło-jonomerowych powłoką nanokompozytową na ich wytrzymałość mechaniczną, twardość oraz proces uwalniania jonów fluoru.

Materiał i metody. Do badań wybrano dwa cementy szkło-jonomerowe Fuji IX GP Fast i ChemFil Rock. Do pokrycia cementu wybrano odpowiedni światłoutwardzalny lakier kompozytowy - G-Coat Plus. Zbadano twardość z wykorzystaniem metody Vickersa oraz średnicową wytrzymałość na rozciąganie (DTS) próbek szkło-jonomerowych przed i po pokryciu ich powłoką nanokompozytową. Uwalnianie jonów fluoru, przed i po pokryciu materiału powłoką ochronną, oceniono za pomocą elektrody jonoselektywnej.

Wnioski. Powłoka G-Coat wpływa istotnie na proces uwalniania jonów fluoru do środowiska wodnego zarówno dla cementu Fuji IX GP Fast, jak i ChemFil Rock. Lakier kompozytowy wpływa znacząco na dynamikę zmian twardości oraz średnicową wytrzymałość na rozciąganie cementu w czasie przechowywania w wodzie.
\end{abstract}

Słowa kluczowe: cementy szkło-jonomerowe, twardość, DTS, uwalnianie jonów, fluor.

\begin{abstract}
Introduction. Glass-ionomer cements are widely used in reconstructive dentistry. This is related to the many advantages of these materials. Taking into account the requirements of modern restorative materials and the possibilities regarding the use of glass-ionomers, studies are being carried out on modifying the surface layer to improve its mechanical properties as well as the aesthetic properties of the fillings.

Aim. The aim of this research was to evaluate the impact of nanocomposite coating on the mechanical properties, hardness and fluoride release of glass-ionomer cement.

Material and Methods. Two commercially available GICs, Fuji IX GP Fast and ChemFil Rock, were selected for this study. Additionally, the corresponding light-cured resin coating G-Coat Plus was chosen. The Vickers hardness and diametral tensile strength (DTS) of the glass-ionomer samples, before and after nanocomposite coating, were measured. Fluoride ion release, before and after coating, was evaluated by ion-selective electrodes.

Results. The G-Coat Plus coating significantly affects the process of releasing fluoride ions into an aqueous environment for both cements: Fuji IX GP Fast and ChemFil Rock. This composite coating has a significant influence on the dynamics of cement hardness changes and diametral tensile strength during storage in water.
\end{abstract}

Keywords: glass-ionomer cements, hardness, DTS, ion release, fluoride.

\section{Wstęp}

W praktyce stomatologicznej do najbardziej popularnych grup materiałów możemy zaliczyć kompozyty, amalgamaty oraz cementy szkło-jonomerowe (GIC) [1]. Cementy szkło-jonomerowe to materiały dwuskładnikowe, składające się z proszku oraz płynu. W trakcie mieszania tych składników zostaje zainicjowana reakcja kwasowo-zasadowa. Kwas reaguje z proszkiem, powodując uwalnianie jonów glinu i wapnia, co prowadzi do wytworzenia soli poliolefinowych wapnia i glinu. Po etapie żelowania następuje utwardzanie materiału [2]. Podczas 
procesu wiązania cement jest bardzo wrażliwy na utratę wody oraz jonów. Jest to istotne w aspekcie klinicznym, ponieważ dostęp do płynu w fazie dojrzewania cementu może wpłynąć na ostateczne właściwości wypełnienia. Jedną z licznych zalet GIC jest zdolność tworzenia trwałego, adhezyjnego wiązania z zębiną oraz ze szkliwem. Materiały te wykazują również największą biotolerancję, małą cytotoksyczność, a ich rozszerzalność termiczna w porównaniu z innymi materiałami stomatologicznymi jest najbardziej zbliżona do tkanek zębów. Ponadto cementy szkło-jonomerowe mają zdolność uwalniania i magazynowania jonów fluoru [3, 4]. Niestety wysoka porowatość, podatność na wilgoć i stosunkowo mała wytrzymałość mechaniczna sprawiają, że materiały te nie są używane w rozległych wypełnieniach zębów [5]. Biorąc pod uwagę możliwości oferowane przez GIC i wymagania stawiane nowoczesnym materiałom do uzupełnień, podjęto próbę polepszenia właściwości mechanicznych konwencjonalnych GIC $[6,7]$. Jednym z nowych rozwiązań oferowanych przez GC Corporation jest zastosowanie powłoki nanokompozytowej, która nie tylko poprawia właściwości estetyczne, ale przede wszystkim chroni materiał przed zużyciem oraz siłami zgryzowymi podczas dojrzewania cementu [8]. Kato i wsp. [9] zbadali wpływ zastosowania różnych lakierów na zmianę właściwości cementów. Wykazano znaczny wzrost wytrzymałości na zginanie dla Fuji IX Extra po pokryciu G-Coat. Wyniki Bonifácio i wsp. [10] są zbliżone i wykazują, że wyższą wytrzymałość na zginanie po pokryciu lakierem G-Coat osiągają materiały Fuji IX GP Extra oraz Ketac Molar Aplicap. Wykazano również, że pokrycie żywiczym lakierem materiałów Equia, Fuji IX GP Fast i Fuji IX GP Extra nie tylko wpływa na zwiększenie wytrzymałości na zginanie, ale poprawia estetykę wypełnień. Lakier kompozytowy sprawia, że wady występujące na powierzchni nie są aż tak widoczne [5]. Odmienne wyniki uzyskał Leirskaret i in. [11]. Wykorzystując w swoich badaniach test ścinania uderzeniowego (ang. punch test), zaobserwowali niższe wartości wytrzymałości na ścinanie próbek Fuji IX GP po pokryciu ich powierzchni lakierem żywiczym bez wypełniacza - Fuji Coat. Autorzy odnotowali istotny wzrost wytrzymałości próbek niepokrytych lakierem tylko w początkowym okresie 1-2 tygodni, kiedy to cement uzyskał docelową wytrzymałość. Sugeruje to, że pokrywanie żywicą może ograniczyć proces hydratacji GIC, zakłócając proces odbudowy (dojrzewania) materiału i ograniczając wzrost jego wytrzymałości.

\section{Cel}

Celem pracy była ocena wpływu pokrycia powierzchni cementów szkło-jonomerowych powłoką nanokompozytową na ich wytrzymałość mechaniczną, twardość oraz proces uwalniania jonów fluoru.

\section{Materiał i metody}

W badaniach wykorzystano dwa szybkowiążące cementy szkło-jonomerowe Fuji IX Fast (GC, Japonia) i ChemFil Rock (Dentsply, Stany Zjednoczone) oraz lakier kompozytowy do pokrycia cementu G-Coat Plus (GC, Japonia) (Tabela 1). Próbki do badań przygotowano, wypełniając materiałem odpowiednie formy silikonowe (wysokość $3 \mathrm{~mm}$ i średnica $6 \mathrm{~mm}$ ). Cementy zarabiano w urządzeniu Silamat S6/Ivoclar-Vivadent w czasie $10 \mathrm{~s}$, wypełniano formę silikonową z nadmiarem, a po usunięciu nadmiarów nakładaczem i wyrównaniu powierzchni materiału przykrywano paseczkiem celuloidowym i mikroskopowym szkiełkiem podstawowym, lekko je uciskając. Po 3 minutach, po związaniu materiału, próbki usuwano z formy i przenoszono na 20 minut do torebek celofanowych, które następnie szczelnie zamykano w celu zapobieżenia dehydratacji materiału podczas wiązania. Następnie powierzchnię próbek delikatnie zmatowiono poprzez szlifowanie papierem ściernym 600P i podzielono losowo na 4 grupy badawcze. Dwie pierwsze grupy - Fuji IX Fast (FF) oraz ChemFil Rock (CR) niepokryte warstwą lakieru - stanowiły grupe kontrolną. Natomiast dwie pozostałe grupy stanowiły próbki z Fuji IX Fast (FFC) i ChemFil Rock (CRC) pokryte warstwą lakieru. Próbki spłukano w strumieniu wody dmuchawki wodno-powietrznej celem usunięcia zanieczyszczeń pozostałych po

Tabela 1. Skład wykorzystanych w badaniu materiałów

Table 1. Composition of tested material

\begin{tabular}{|l|l|l|}
\hline \multicolumn{1}{|c|}{ Materiał } & \multicolumn{1}{|c|}{ Producent } & \multicolumn{1}{c|}{ Skład } \\
\hline GC Fuji IX GP Fast & GC Europe N.V., Belgia & $\begin{array}{l}\text { szkło fluoro-glinowo-krzemowe, kwas polialkenowy, woda destylo- } \\
\text { wana, polikwas karboksylowy }\end{array}$ \\
\hline ChemFil Rock & Dentsply, Niemcy & $\begin{array}{l}\text { szkło wapniowo-glinowo-cynkowo-fosforanowo-krzemowe, kwas } \\
\text { polialkenowy, woda destylowana, tlenek żelaza, tlenek tytanu, } \\
\text { kwas winowy }\end{array}$ \\
\hline GC G-Coat Plus & GC Europe N.V., Belgia & \\
\hline
\end{tabular}


szlifowaniu i osuszono powietrzem. Powierzchnię próbek grup FFC i CRC pokryto G-Coat Plus. Lakier utwardzano światłem lampy polimeryzacyjnej Elipar S10 (3M-ESPE, Niemcy), naświetlając każdą powierzchnię próbki przez 20 s. Próbki wszystkich grup zamknięto $w$ oddzielnych pojemnikach szklanych w $100 \mathrm{ml}$ wody destylowanej i przechowywano przez okres od 1 do 21 dni w temperaturze pokojowej, wykonując w określonych interwałach czasowych badania twardości i wytrzymałości badanych materiałów. Dodatkowo wydzielono po 2 próbki z każdej grupy badawczej do oceny procesu uwalniania jonów fluoru.

Do pomiaru ilości uwolnionych jonów fluorkowych zastosowano $\mathrm{pH}$-jonometr $\mathrm{CPI} 505$ (Elmetron, Polska) z fluorkową elektrodą jonoselektywną. Próbki umieszczono w $10 \mathrm{ml}$ roztworu stabilizującego, otrzymanego przez wymieszanie 10 cz. obj. TISAB III (Hydromet, Polska) oraz 100 cz. obj. wody ultraczystej o rezystancji wynoszącej 18,2 m $\Omega$. Próbki następnie inkubowano w temperaturze $37,0 \pm 0,2{ }^{\circ} \mathrm{C}$. Pomiar przeprowadzano codziennie przez okres 10 dni w temperaturze pokojowej. Na podstawie uzyskanych wyników obliczono ilość uwalnianych jonów fluorkowych.

Do oceny wytrzymałości próbek materiału wykorzystano metodę badania średnicowej wytrzymałości na rozciąganie, ściskając próbki wzdłuż ich średnicy w uniwersalnym urządzeniu do badań wytrzymałościowych Zwick-Roell Z020 (Zwick/ Roell, Niemcy) przy prędkości belki poprzecznej $2 \mathrm{~mm} / \mathrm{min}$. Średnicowa wytrzymałość na rozciąganie jest to maksymalna odporność materiału na obciążenia zmierzające do zniszczenia próbki. Wartość liczbową oblicza się według następującego wzoru:

DTS $[\mathrm{MPa}]=\frac{\mathrm{P}}{\mathrm{S}} \frac{[\mathrm{N}]}{\left[\mathrm{mm}^{2}\right]}=\frac{\mathrm{P}}{\frac{1}{2}\left(2 \pi \frac{\mathrm{D}}{2} \mathrm{~T}\right)}=\frac{2 \mathrm{P}}{\pi \mathrm{DT}} \frac{[\mathrm{N}]}{\left[\mathrm{mm}^{2}\right]}$

gdzie:

DTS - średnicowa wytrzymałość na rozciąganie [MPa],

P - przyłożona siła [N],

S - powierzchnia $\left[\mathrm{mm}^{2}\right]$,

D - średnica próbki [mm],

T - grubość próbki [mm].

Wytrzymałość próbek poszczególnych grup badawczych oceniono po 24 godz. oraz po 3, 7, 14 i 21 dniach. W każdym interwale czasowym wykonano dla każdej grupy po 11 pomiarów.

Materiały poddano również badaniu twardości metodą Vickersa, wykorzystując mikrotwardościomierz ZH1 (Zwick/Roell). Badanie przeprowadzono przy obciążeniu penetratora $1000 \mathrm{G}$ w czasie 10 sekund (HV1/10). Pomiędzy odciskami zachowywano odstęp co najmniej 3 przekątnych odcisku.
Na każdą serię badań w poszczególnych interwałach czasowych (1, 3, 7, 14 i 21 dni) przeprowadzono po 7 pomiarów twardości.

Sprawdzono zgodność rozkładu zmiennych $z$ rozkładem normalnym $z$ wykorzystaniem testu Shapiro-Wilka. Zastosowano elementy statystyk opisowych i wyznaczono średnie, mediany, odchylenia standardowe, wartości maksymalne i minimalne. Sprawdzono jednorodność wariancji z wykorzystaniem testu Levene'a.

Porównano wyniki prób z powłoką kompozytową z wynikami prób bez powłoki w kolejnych dniach pomiarowych. W przypadku zgodności rozkładu zmiennych z rozkładem normalnym użyto testu $t$, gdy wariancje były jednorodne, lub testu $t$ z oddzielną estymacją wariancji, gdy wariancje nie były jednorodne. Przy braku zgodności rozkładu zmiennych z rozkładem normalnym do porównania wykorzystano test $U$ Manna-Whitneya.

Oceniono różnice $w$ wynikach dla prób $z$ powłoką oraz bez powłoki między kolejnymi dniami pomiarowymi $z$ wykorzystaniem testu ANOVA. $\mathrm{W}$ przypadku istnienia różnic $\mathrm{w}$ teście Friedmana zastosowano test post-hoc Tukeya. W przypadku braku zgodności z rozkładem normalnym zastosowano test ANOVA Kruskalla-Wallisa. Przyjęto poziom istotności $\alpha=0,05$.

\section{Wyniki i dyskusja}

Tradycyjne cementy szkło-jonomerowe mają unikalne właściwości, które decydują o ich szerokim zastosowaniu jako materiałów do wypełnień, podkładowych, cementów protetycznych czy systemów wiążące. Jednakże, wykazują one pewne ograniczenia kliniczne, takie jak: stosunkowo niska odporność na pękanie, sztywność, długotrwały proces utwardzania oraz wrażliwość na wilgoć w okresie wiązania materiału. Podczas dojrzewania cementu w jamie ustnej sorpcja wody lub jej utrata mogą mieć negatywny wpływ na ostateczne właściwości mechaniczne wypełnienia [12]. Wprowadzenie systemu Equia Coat jest nowością w dziedzinie poprawy właściwości uzupełnień GIC. Zastosowana powłoka jest ciekłym, samoadhezyjnym nanokompozytem o bardzo małej lepkości i dużej hydrofilowości. Nanonapełniacz ma zapewnić powstanie warstwy odpornej na ścieranie, zmniejszającej zużycie materiału podczas żucia. Powłoka ta ma na celu ochronę wypełnienia szczególnie w pierwszych dniach, kiedy cement nie jest w pełni utwardzony [8].

W badaniach własnych zaobserwowano, że próbki przygotowane z Fuji IX Fast uwalniają najwięcej fluorku z powierzchni materiału podczas pierwszych 48 godzin. Pomiędzy 3 a 7 dobą zauważono zmniejszenie ilości uwolnionych jonów 
fluoru, po czym nastąpiło ustabilizowanie na poziomie 12 ppm. Jest to zgodne z wynikami innych badań [13-15]. Porównując krzywą dla Fuji IX Fast z warstwą G-Coat Plus, można zauważyć, że ilość uwolnionych jonów fluorkowych do roztworu stopniowo wzrasta z upływem czasu do 21 ppm po 10 dniach przechowywania w wodzie (Rycina 1).
Próbki ChemFil Rock wykazują znacznie niższe ilości uwolnionych jonów fluorkowych w porównaniu do próbek cementu Fuji IX Fast (Ryciny 1, 2). Badanie przeprowadzone przez Prestona i wsp. [16] wykazały, że Ketac Nano wykazywał wyższe uwalnianie fluorków w porównaniu z ChemFil Rock. Wykazano także, że cement Fuji IX Fast wy-

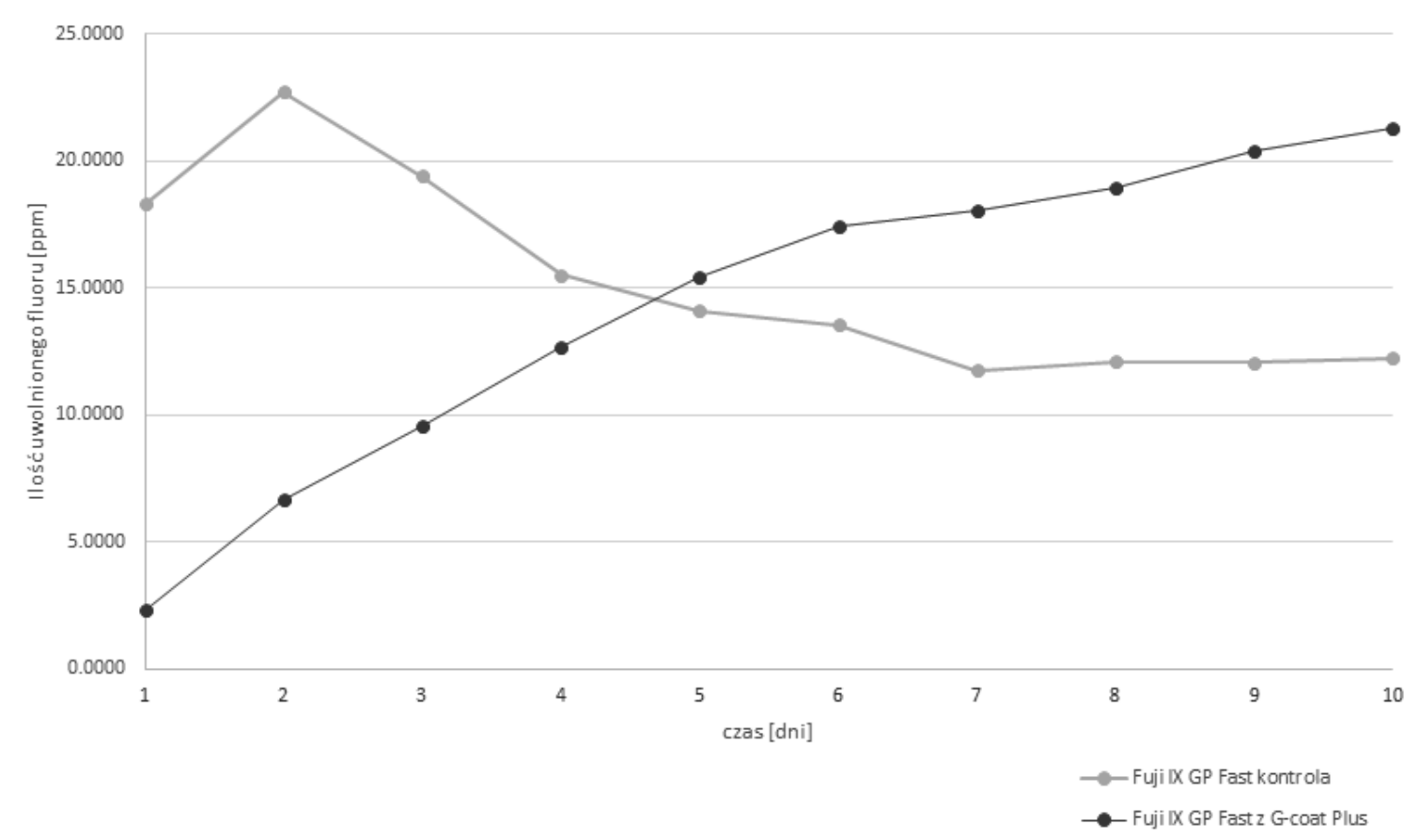

Rycina 1. Poziom uwolnionych jonów fluoru z próbek Fuji IX Fast niepokrytego i pokrytego warstwą lakieru G-Coat Plus Figure 1. Level of released fluoride ions from Fuji IX Fast samples uncoated and coated with G-Coat Plus

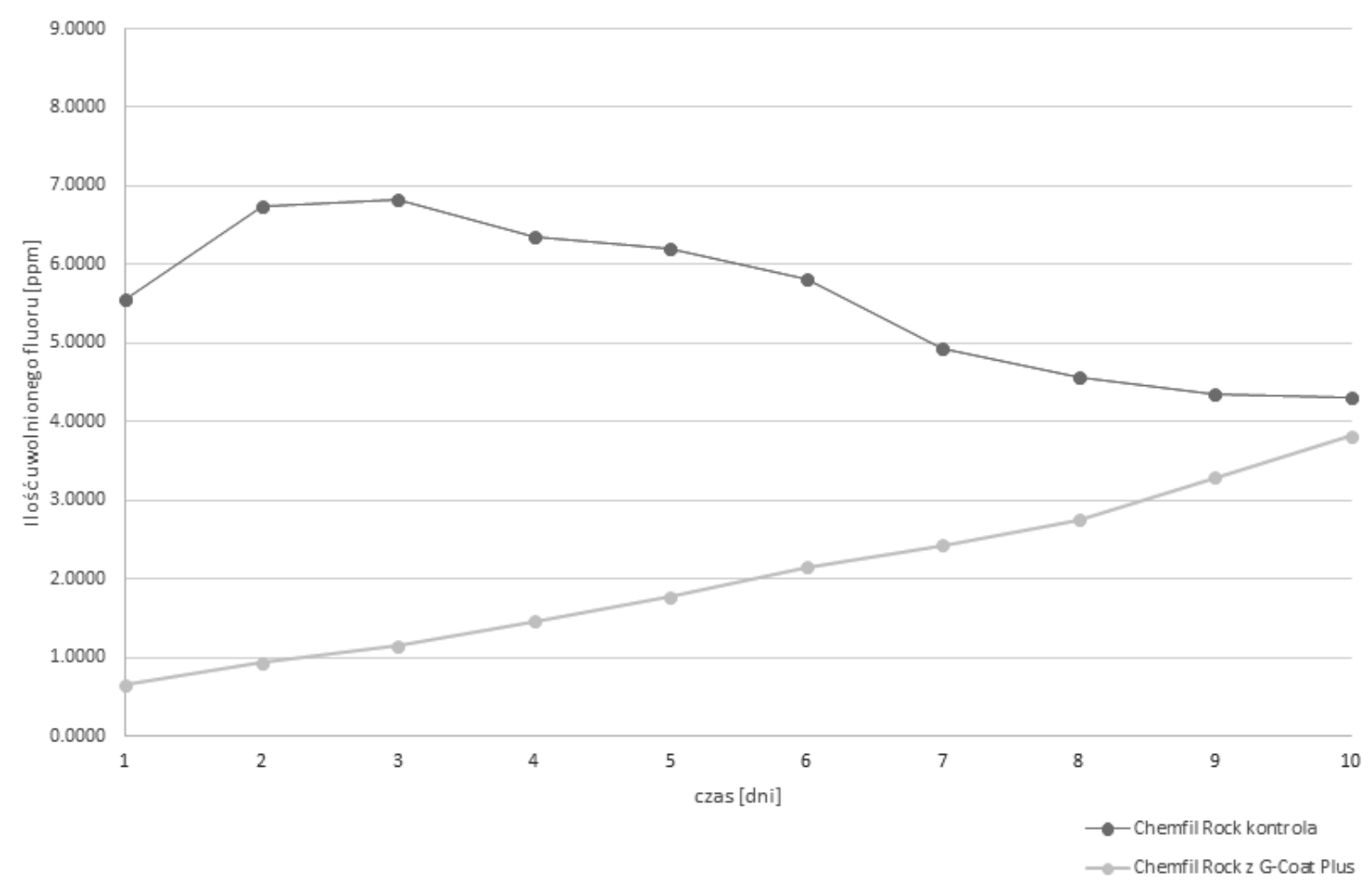

Rycina 2. Poziom uwolnionych jonów fluoru z próbek ChemFil Rock niepokrytego i pokrytego warstwą lakieru G-Coat Plus Figure 2. Level of released fluoride ions from ChemFil Rock samples uncoated and coated with G-Coat Plus 
kazuje najwyższe uwalnianie jonów fluorkowych w porównaniu $z$ innymi badanymi materiałami [17, 18], co jest zgodne z naszymi wynikami badań. Mniejsza ilość uwalnianych jonów $\mathrm{F}^{-} \mathrm{z}$ materiału ChemFil Rock, w porównaniu z Fuji IX Fast, wynika $z$ jego składu. Znajduje się w nim dodatek szkła zawierającego cynk (poprawia on właściwości wytrzymałościowe), które jednak nie bierze czynnego udziału w reakcji kwasowo-zasadowej zachodzącej w trakcie utwardzania materiału.

Należy również podkreślić charakter dynamiki uwalnianych jonów fluoru dla materiałów pokrytych lakierem i bez powłoki ochronnej. Materiały pokryte powłoką charakteryzują się stopniowym, ciągłym uwalnianiem fluorku w porównaniu do ma- teriałów niepokrytych. Może to działać korzystnie na systematyczne wchłanianie fluorku przez zdemineralizowane tkanki zęba (Rycina 2). Badania wykazały, że pokrycie próbek ChemFil Rock powłoką, podobnie jak w przypadku Fuji IX Fast, powoduje wolniejsze, ale ciągłe uwalnianie jonów fluoru. Najszybsze uwalnianie anionów $\mathrm{F}^{-}$dla próbek kontrolnych występuje po pierwszych 24 godzinach od zmieszania cementu. Wynika to $z$ reakcji zachodzącej w materiale, a także preferencyjnego uwalniania jonów z powierzchni cementu [19]. Reakcja GIC jest reakcją kwasowo-zasadową pomiędzy roztworem elektrolitu a szkłem glinowo-krzemowym. Polikwasy reagują ze szkłem, powodując uwalnianie kationów metali i anionów fluorkowych.

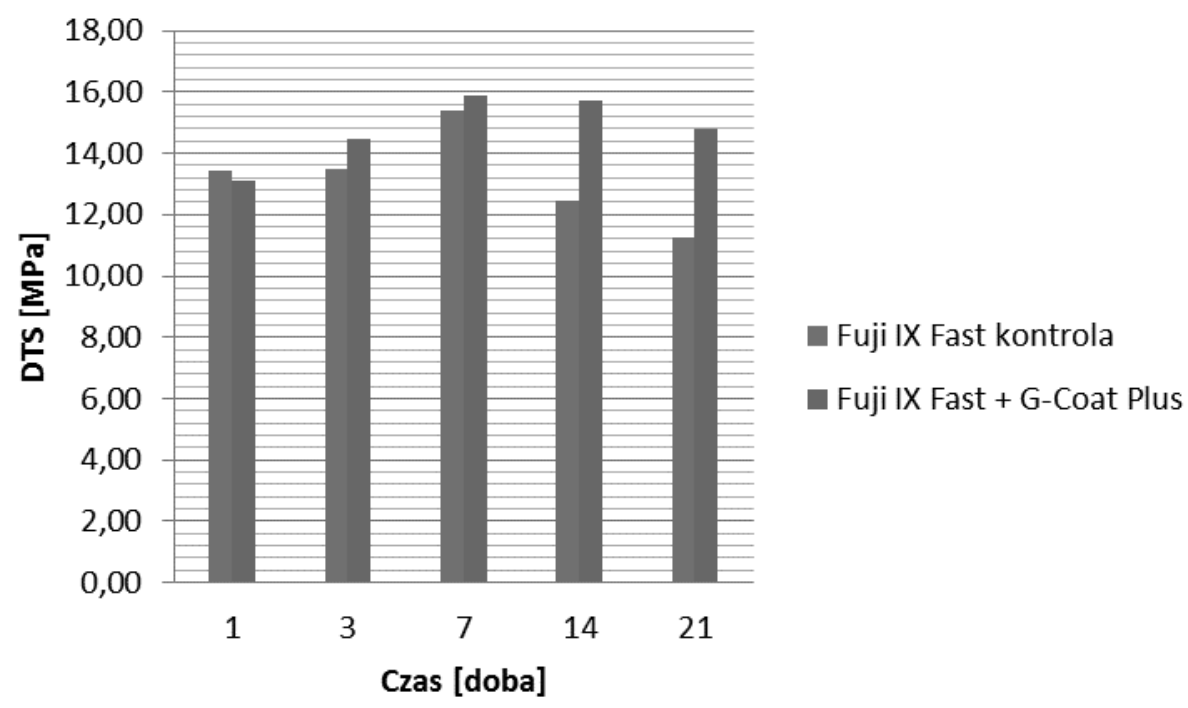

Rycina 3. Wyniki badania średnicowej wytrzymałości na rozciąganie dla próbek Fuji IX Fast niepokrytych i pokrytych warstwą lakiery G-Coat Plus

Figure 3. The results of Diametral Tensile Strength of samples Fuji IX Fast uncoated and coated with G-Plus Coat

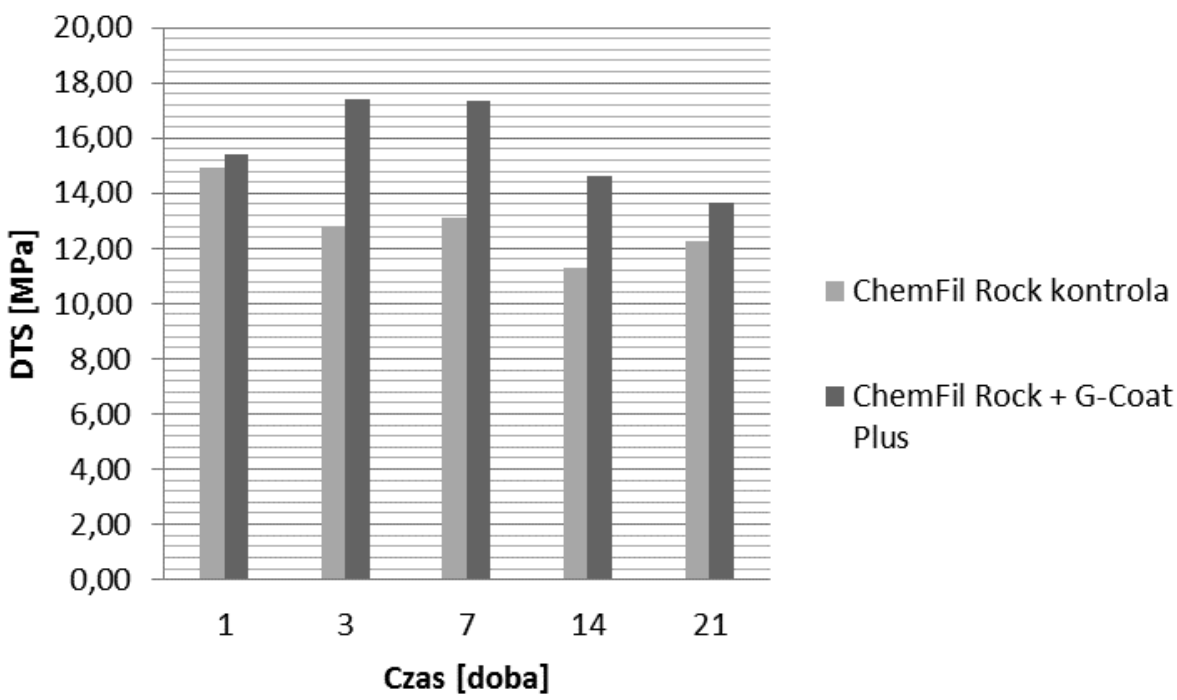

Rycina 4. Wyniki badania średnicowej wytrzymałości na rozciąganie dla próbek ChemFil Rock niepokrytych i pokrytych warstwą lakiery G-Coat Plus

Figure 4. The results of Diametral Tensile Strength of samples ChemFil Rock uncoated and coated with G-Plus Coat 
Jony fluorkowe i fosforanowe tworzą nierozpuszczalne sole i kompleksy, natomiast jony krzemianowe - żel krzemionkowy [2]. Zmniejszenie ilości uwolnionych jonów fluorkowych obserwowanych na wykresie dla próbek bez warstwy lakieru (Ryciny 1, 2) wynika $z$ wyczerpania się rezerwuaru jonów fluorkowych znajdujących się w hydrożelu krzemionkowym. Mniejsze ilości jonów fluoru są następnie powoli uwalniane ze szkła.

W przypadku próbek obu badanych cementów z powłoką można obserwować silne blokowanie uwalniania jonów przez warstwę G-Coat Plus (Ryciny 1, 2). Warto podkreślić, że w warunkach klinicznych powłoka ma za zadanie ochronić materiał przed siłami zgryzowymi, ale także przed nadmiernym wypłukiwaniem jonów $\mathrm{F}^{-}$i $\mathrm{Ca}^{2+}$ przez ślinę do środowiska jamy ustnej. Nie koliduje to jednak z pożądaną remineralizacją zębiny w wyniku wolnej dyfuzji jonów do tkanek zęba.

W badaniach własnych w grupach kontrolnych odnotowano zmiany wartości wytrzymałości (DTS) w trakcie przechowywania próbek w wodzie. W toku analizy statystycznej stwierdzono istnienie istotnej różnicy statystycznej ( $p$-value $=0,0068)$ między 7 a 21 dniem przechowywania w wodzie dla próbek Fuji IX GP Fast (Rycina 3). W przypadku materiału ChemFil Rock, na podstawie testu post-hoc Turkey, wykazano istotną różnicę między 1 a 14 dniem ( $p$-value $=0,0230$ ) (Rycina 4). W przypadku grup badawczych pokrytych warstwą G-coat Plus różnice $w$ uzyskanych wartościach okazały się nieistotne statystycznie (Ryciny 3, 4).

Stwierdzenie istotnie większej wytrzymałości próbek cementu Fuji IX Fast pokrytych G-Coat i przechowywanych w wodzie przez 14 i 21 dni w porównaniu z próbkami niepokrytymi warstwą lakieru jednoznacznie wskazuje na możliwości ochrony wypełnienia szkło-jonomerowego w okresie dojrzewania (przebudowy), gdy cement jest szczególnie narażony na ścieranie i uszkodzenia mechaniczne. Należy również wskazać na istotnie większe wartości w wytrzymałości próbek cementu ChemFil Rock pokrytych warstwą lakieru w porównaniu z próbkami kontrolnymi w 3, 7 oraz 14 dniu przechowywania w wodzie. Powłoka ochronna $w$ tym okresie $w$ pełni zabezpiecza wypełnienie przed nadmiernym zużyciem. Krytycznym okresem dla cementów szkło-jonomerowych jest okres tuż po wykonaniu wypełnienia, ponieważ w ciągu 24 godzin następuje dynamiczny wzrost wytrzymałości materiału. W kolejnych dniach tempo wzrostu wytrzymałości ulega spowolnieniu, a nawet wytrzymałość nieznacznie spada. Może być to wytłumaczone przez zachodzący proces sorpcji wody.

Niestety niemożliwe jest bezpośrednie porównanie wyników badań własnych z rezultatami prac innych autorów, ponieważ istnieje zbyt mała ilość prac poświęconych temu zagadnieniu. Dodatkowo opisane w nich badania prowadzone były z reguły w oparciu o odmienne metody, przy użyciu różnych cementów szkło-jonomerowych. Możliwe jest jednak porównanie wyników w zakresie jakościowej oceny zachodzących zjawisk. Wang i in. [20] zbadali wpływ pokrycia G-Coat na wytrzymałość na ścinanie różnych cementów szkło-jonomerowych (4 tradycyjnych cementów i 1 szkło-jonomeru modyfikowanego żywicą). Oceny wytrzymałości dokonali testem wycinania (ang. punch test) po 4 tygodniach przechowywania próbek w wodzie. Wyniki ich badań są zbieżne z rezultatami niniejszej pracy, stwierdzili bowiem, że powłoka G-Coat wpływa istotnie na wytrzymałość Ketac Molar Quick i Ketac Molar, dla pozostałych materiałów wartości wytrzymałości są zbliżone.

W badaniach własnych uzyskano istotny wzrost twardości próbek kontrolnych cementu ChemFil Rock. Twardość tego materiału po 24 godzinach wynosiła $17 \mathrm{HV}$, następnie w przeciągu całego okresu badań rosła, osiągając $49 \mathrm{HV}$ po 21 dniach (Rycina 6). Wzrost twardości cementu ChemFil Rock jest związany z dojrzewaniem materiału i uzyskaniem większej wytrzymałości. Przedłużony czas dojrzewania cementu Chemfil Rock w porównaniu do Fuji IX Fast (Ryciny 5, 6) wynika z obecności w jego składzie kwasu winowego, który działa plastyfikująco i wydłuża czas wiązania. W badaniach zauważono, że w przypadku próbek Fuji IX Fast maksymalną twardość osiągnięto po 24 godzinach, następnie zaobserwowano nieznaczny jej spadek (Rycina 5). Jest to zapewne związane z sorpcją wody, prowadzącą do pęcznienia materiału, a w konsekwencji do rozluźnienia sieci przestrzennej (struktury wewnętrznej) i zmniejszenia twardości materiału. Dodatkowo obserwowane znaczne wahania twardości próbek kontrolnych w poszczególnych dniach badania mogą być wytłumaczone anizotropową strukturą cementu i przypadkowością pomiarów. Mimo iż wartość twardości poszczególnych próbek była średnią z 7 pomiarów, to kwestią przypadku był pomiar w miejscach, gdzie były zlokalizowane cząstki szkła, o dużej twardości, bądź w obszarze otaczającym cząstki napełniacza, który odznacza się niższą twardością.

W przypadku grup badawczych pokrytych warstwą G-Coat Plus nie stwierdzono występowania istotnej statystycznie różnicy pomiędzy poszczególnymi dniami dla prób ChemFil Rock (Rycina 6). W przypadku cementu Fuji IX Fast stwierdzono istotną różnicę pomiędzy 1 a 21 dniem przechowywania próbek w wodzie ( $p$-value $=0,0447)(\mathbf{R y}$ cina 5). Analizując zmiany twardości próbek po- 


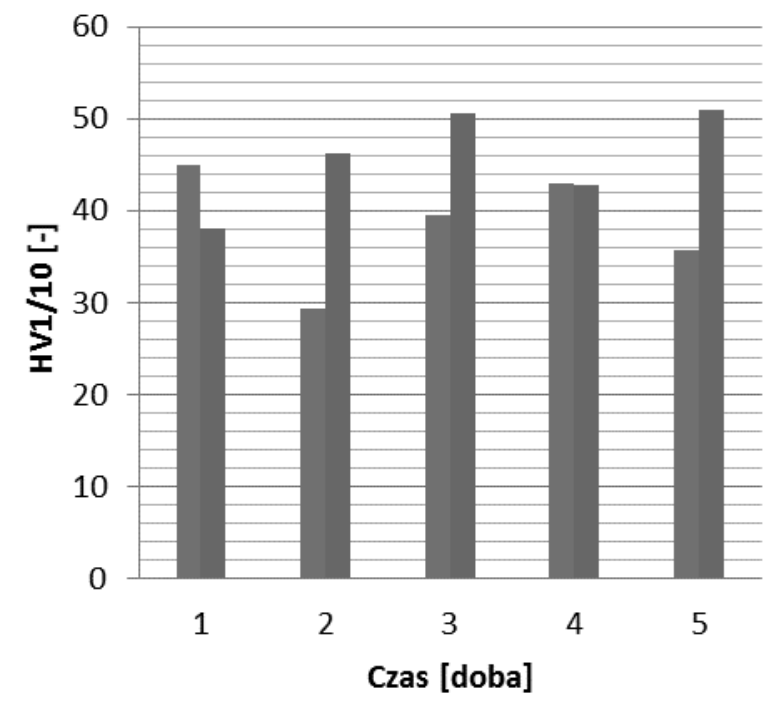

- Fuji IX Fast kontrola

Fuji IX Fast + G-Coat Plus

Rycina 5. Wyniki pomiarów twardości dla próbek Fuji IX Fast niepokrytych i pokrytych warstwą lakieru G-Coat Plus Figure 5. The results of hardness of samples Fuji IX Fast uncoated and coated with G-Plus Coat

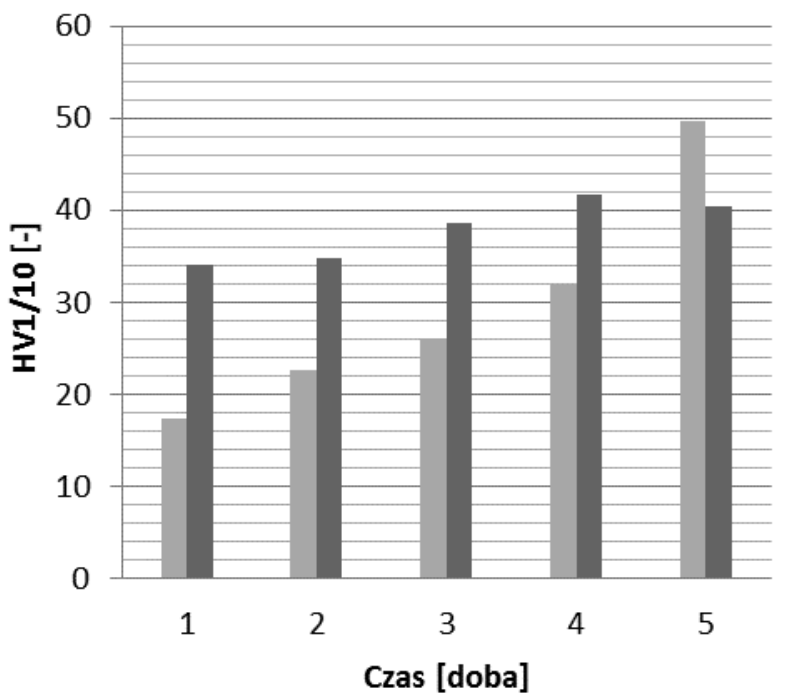

- ChemFil Rock kontrola

- ChemFil Rock + G-Coat Plus

Rycina 6. Wyniki pomiarów twardości dla próbek ChemFil Rock niepokrytych i pokrytych warstwą lakieru G-Coat Plus Figure 6. The results of hardness of samples ChemFil Rock uncoated and coated with G-Plus Coat

krytych warstwą lakieru trzeba mieć na uwadze warunki niniejszego badania. Grubość powłoki G-Coat Plus wynosi ponad $100 \mu \mathrm{m}$, a penetrator w teście Vickersa, przy obciążeniu $1000 \mathrm{G}$, zagłębia się w materiał na ok. $250 \mu \mathrm{m}$, zatem po przebiciu powłoki tylko część penetratora zagłębia się w cemencie. Zmiany twardości w kolejnych dniach są więc wynikiem zmian twardości nie tylko cementu, ale także powłoki. Początkową twardość próbek pokrytych powłoką G-Coat Plus można wiązać $w$ dużej mierze $z$ sieciowaniem polimerowej matrycy powłoki. W kolejnych dniach zachodziły równocześnie dwa procesy wpływające na otrzymane wartości twardości. Pierwszym procesem był spowolniony proces dojrzewania cementu, spowodowany zastosowaniem lakieru kompozytowego, który ograniczył dostęp wody. Drugim procesem, powszechnym w środowisku wodnym, była sorpcja, która powoduje spadek twardości przez rozluźnienie struktury zarówno cementu, jak i powłoki. Materiały kompozytowe także chłoną wodę, choć w mniejszym stopniu niż cementy szkło-jonomerowe [21]. Dodatkowo na mniejsze wahania twardości próbek pokrytych G-Coat w czasie badania z pewnością wpłynęły własności powłoki nanokompozytowej, bardziej jednorodnej pod względem mikrostruktury w porównaniu z cementem szkło-jonomerowym.

W toku analizy statystycznej stwierdzono istotnie większą twardość próbek ChemFil Rock pokrytych G-Coat Plus w porównaniu z grupą kontrolną w dniach 1, 3, 7 oraz 14 przechowywania w wodzie (Rycina 6). W przypadku materiału Fuji IX Fast pokrytego lakierem zaobserwowano istot- 
nie wyższe wartości w dniach 3,7 oraz 21 (Rycina 5). Statystycznie wyższa twardość cementu pokrytego warstwą nanokompozytu w pierwszych dniach wskazuje na potencjalne możliwości ochrony cementu szkło-jonomerowego przed nadmiernym zużyciem abrazyjnym. Związane jest to nie tylko z wyższą twardością, ale także gładkością powierzchni powłoki $[5,22]$ oraz jej charakterem - warstwą kompozytową. Jak wynika z wcześniej prowadzonych badań, materiał kompozytowy Filtek Z100 cechuje niższa ścieralność w porównaniu z cementami szkło-jonomerowymi oraz kompomerami [23]. Znajduje to potwierdzenie w wynikach 3-letnich badań klinicznych wypełnień wykonanych z cementu szkło-jonomerowego Fuji IX GP Extra oraz materiału kompozytowego, które zastosowano w pierwszych stałych zbach trzonowych u dzieci. Dowiodły one, które dowodzą korzystnego działania powłoki G-Coat. Autorzy odnotowali brak zmiany koloru wypełnień szkło-jonomerowych, tak z powłoką G-Coat, jak i bez niej. Dodatkowo wypełnienia pokryte G-Coat wykazywały nieznacznie mniejszy stopień starcia, lecz jednocześnie nieco wyższy niż wypełnień kompozytowych. Autorzy donoszą, że chociaż różnice nie były statystycznie istotne, to wskazują na możliwość ochrony przez G-Coat powierzchni wypełnień szkło-jonomerowych przed zużyciem w warunkach klinicznych [24]. Także Klinkeet i wsp. [25] $w$ badaniach klinicznych dowiedli istotnie lepszej jakości wypełnień z cementu szkło-jonomerowego Equia Fill pokrytego G-Coat w porównaniu $z$ wypełnieniami z cementu szkło-jonomerowego Fuji IX, wskazując jednocześnie na relatywnie wysoki odsetek niepowodzeń w przypadku wypełnień II klasy.

W badaniach własnych stwierdzono tylko w niektórych interwałach czasowych istotnie większe różnice w wytrzymałości mechanicznej zbadanych cementów szkło-jonomerowych pokrytych G-Coat Plus w porównaniu z materiałem niepokrytym. Może to sugerować, że warstwa lakieru kompozytowego nie tylko nie zaburza w znaczący sposób procesu dojrzewania materiału, ale wpływa korzystnie na właściwości mechaniczne wypełnienia.

Należy podkreślić, że wytrzymałość mechaniczna cementów szkło-jonomerowych zależy w dużej mierze od prawidłowego bilansu wody $w$ trakcie dojrzewania materiału. Zarówno nadmiar wody, jak i dehydratacja podczas początkowych faz wiązania materiału wpływają niekorzystnie na fizyczne i mechaniczne właściwości wypełnień z cementu szkło-jonomerowego [26]. W celu zapobieżenia tym niekorzystnym zmianom zaleca się pełną izolację wypełnień od środowiska zewnętrz- nego w początkowej fazie wiązania materiału, określanej na od co najmniej 60 minut do nawet dwóch tygodni od momentu zmieszania materiału. Wytworzone warstwy ochronne w trakcie żucia pokarmów ulegają starciu, jednak w okresie ochrony zapewniają cementom odpowiedni bilans wodny, pozwalający na przebudowę materiału, który w wyniku dojrzewania staje się bardziej odporny na czynniki chemiczne i mechaniczne [26]. Ponadto doniesienia o istotnym wzroście wytrzymałości cementów szkło-jonomerowych na zginanie po pokryciu powłoką G-Coat $[5,9,10,27]$ i zmniejszeniu zużycia materiału w warunkach klinicznych [24] świadczą o niezmiernie korzystnym działaniu G-Coat jako powłoki ochronnej.

\section{Wnioski}

Powłoka G-Coat wpływa istotnie na proces uwalniania jonów fluoru do środowiska wodnego zarówno przez cement Fuji IX Fast, jak i ChemFil Rock. Lakier kompozytowy wpływa znacząco na dynamikę zmian twardości cementu w czasie przechowywania w wodzie. Stwierdzono również istotny wpływu powłoki na średnicową wytrzymałość na rozciąganie.

Wyższe wartości twardości i DTS dla próbek pokrytych G-Coat w porównaniu z cementem niepokrytym powłoką stwarzają potencjalne możliwości ochrony wypełnień szkło-jonomerowych przed starciem i mechanicznym uszkodzeniem we wczesnym okresie, kiedy wypełnienie jest szczególnie narażone na mechaniczne uszkodzenia. Dodatkowo warstwa lakieru chroni materiał przed nadmiernym wypłukiwaniem jonów F- przez ślinę do środowiska jamy ustnej, skutkiem czego może być bardziej efektywna, pożądana remineralizacja nakierowana na zębinę.

\section{Oświadczenia}

\section{Oświadczenie dotyczące konfliktu interesów}

Autorzy deklarują brak konfliktu interesów w autorstwie oraz publikacji pracy.

\section{Źródła finansowania}

Autorzy deklarują brak źródeł finansowania.

\section{Piśmiennictwo}

[1] Lohbauer U. Dental glass ionomer cements as permanent filling materials? Properties, limitations and future trends. Materials (Basel). 2010;3(1):76-96. Doi: 10.3390/ ma3010076.

[2] Crisp S, Wilson AD. Reactions in Glass Ionomer Cements I. Decomposition of the Powder. J Dent Res. 1974;53(6):1408-1413.

[3] Sidhu S, Nicholson J. A Review of Glass-Ionomer Cements for Clinical Dentistry. J Funct Biomater. 2016;7(3):16. Doi: 10.3390/jfb7030016.

[4] Author C, Aminzare M, Khademolhosseini MR, et al. Development of New Al 2 O 3 /TiO 2 Reinforced Glass- 
Ionomer Cements (GICs) Nano-Composites. J Basic Appl Sci Res. 2012;2(8):7526-7529.

[5] Zoergiebel J, llie N. Evaluation of a conventional glass ionomer cement with new zinc formulation: Effect of coating, aging and storage agents. Clin Oral Investig. 2013;17(2):619-626. Doi: 10.1007/s00784-012-0733-1.

[6] Gjorgievska E, Van Tendeloo G, Nicholson JW, Coleman NJ, Slipper IJ, Booth S. The Incorporation of Nanoparticles into Conventional Glass-lonomer Dental Restorative Cements. Microsc Microanal. 2015;21(2):392-406. Doi: 10.1017/S1431927615000057.

[7] Moshaverinia A, Ansari S, Movasaghi Z, Billington RW, Darr J a., Rehman IU. Modification of conventional glass-ionomer cements with $\mathrm{N}$-vinylpyrrolidone containing polyacids, nano-hydroxy and fluoroapatite to improve mechanical properties. Dent Mater. 2008;24(10):1381-1390. Doi: 10.1016/j.dental.2008.03.008.

[8] Basso $\mathrm{M}$. Teeth restoration using a high-viscosity glass ionomer cement: the Equia ${ }^{\circledR}$ system. J Minim Interv Dent. 2011;4:74-77.

[9] Kato K, Yarimizu H, Nakaseko H, Sakuma T. Influence of coating material on conventional glass-ionomer cement. J Dent Res. 2008;87(Special Issue B).

[10] Bonifácio CC, Werner A, Kleverlaan CJ. Coating glass-ionomercementswithananofilledresin. ActaOdontolScand. 2012;70(6):471-477. Doi: 10.3109/00016357.2011.639307.

[11] Leirskar J, Nordbø H, Mount GJ, Ngo H. The influence of resin coating on the shear punch strength of a high strength auto-cure glass ionomer. Dent Mater. 2003;19(2):87-91. Doi: 10.1016/S0109-5641(02)00016-7.

[12] Pereira LC, Nunes MCP, Dibb RGP, Powers JM, Roulet $J-F$, Navarro MFDL. Mechanical properties and bond strength of glass-ionomer cements. J Adhes Dent. 2002;4(1):73-80.

[13] Bell a, Creanor SL, Foye RH, Saunders WP. The effect of saliva on fluoride release by a glass-ionomer filling material. J Oral Rehabil. 1999;26(5):407-12. Doi: 10.1046/j.1365 $-2842.1999 .00389 . x$

[14] Wiegand A, Buchalla W, Attin T. Review on fluoride-releasing restorative materials-Fluoride release and uptake characteristics, antibacterial activity and influence on caries formation. Dent Mater. 2007;23(3):343-362. Doi: 10.1016/j.dental.2006.01.022.

[15] Hammouda IM, Al-Wakeel EE. Effect of water storage on fluoride release and mechanical properties of a polyacid-modified composite resin (compomer). J Biomed Res. 2011;25(4):254-258. Doi: 10.1016/S16748301(11)60034-1.

[16] Preston AJ, Agalamanyi E a, Higham SM, Mair LH. The recharge of esthetic dental restorative materials with fluoride in vitro-two years' results. Dent Mater. 2003;19(1):3237. Doi: 10.1016/S0109-5641(02)00011-8.

[17] Xu X, Burgess JO. Compressive strength, fluoride release and recharge of fluoride-releasing materials. Biomaterials. 2003;24(14):2451-2461. Doi: 10.1016/S01429612(02)00638-5.
[18] Cabral MFC, Martinho RLDM, Guedes-Neto MV, RebeIo MAB, Pontes DG, Cohen-Carneiro F. Do conventional glass ionomer cements release more fluoride than resin-modified glass ionomer cements? Restor Dent Endod. 2015;40(3):209-15. Doi: 10.5395/rde.2015.40.3.209.

[19] Kuhn AT, Wilson AD. The dissolution mechanisms of silicate and glass-ionomer dental cements. Biomaterials. 1985;6(6):378-382.

[20] Wang XY, Yap AUJ, Ngo HC. Effect of early water exposure on the strength of glass ionomer restoratives. Oper Dent. 2006;31(5):584-589. Doi: 10.2341/05-106.

[21] Dinakaran S. Sorption and solubility characteristics of compomer, conventional and resin modified glass - ionomer immersed in various media. J Dent Med Sci. 2014;13(3):41-45.

[22] Bagis B, Tüzüner T, Turgut $S$, Korkmaz FM, Baygin $\mathrm{O}, \mathrm{Ba}$ is $\mathrm{YH}$. Effects of protective resin coating on the surface roughness and color stability of resin-based restorative materials. Sci World J. 2014;2014. Doi: 10.1155/2014/832947.

[23] Peutzfeldt A, García-Godoy F, Asmussen E. Surface hardness and wear of glass ionomers and compomers. Am J Dent. 1997;10(1):15-17.

[24] Diem VTK, Tyas MJ, Ngo HC, Phuong LH, Khanh ND. The effect of a nano-filled resin coating on the 3-year clinical performance of a conventional high-viscosity glass-ionomer cement. Clin Oral Investig. 2014;18(3):753-759. Doi: 10.1007/s00784-013-1026-z.

[25] Klinke T, Daboul A, Turek A, Frankenberger R, Hickel R, Biffar R. Clinical performance during 48 months of two current glass ionomer restorative systems with coatings: a randomized clinical trial in the field. Trials. 2016;17(1):239. Doi: 10.1186/s13063-016-1339-8.

[26] Naasan MA, Watson TF. Conventional glass ionomers as posterior restorations: A status report for the American Journal of Dentistry. Am J Dent. 1998;11(1):36-45.

[27] Gorseta K, Glavina D, Skrinjaric T, Czarnecka B, Nicholson JW. The effect of petroleum jelly, light-cured varnish and different storage media on the flexural strength of glass ionomer dental cements. Acta Biomater Odontol Scand. 2016;2(1):55-59. Doi: 10.3109/23337931.2016.1160784.

Zaakceptowano do edycji: 2017-09-01

Zaakceptowano do publikacji: 2017-11-01
Adres do korespondencji:
Agata Szczesio
ul. Pomorska 251, 92-213 tódź
tel.: 422725766
e-mail: agata.szczesio@umed.lodz.pl 